\title{
Strongyloides venezuelensis Alkaline Extract for the Diagnosis of Human Strongyloidiasis by Enzyme-linked Immunosorbent Assay
}

\author{
Eleuza Rodrigues Machado, Marlene Tiduko Ueta, \\ Maria do Rosário de Fátima Gonçalves-Pires*, João Batista Alves de Oliveira, \\ Lúcia Helena Faccioli**, Julia Maria Costa-Cruz*/+
}

\begin{abstract}
Departamento de Parasitologia, Instituto de Biologia, Universidade Estadual de Campinas, SP, Brasil *Laboratório de Parasitologia, Departamento de Imunologia, Microbiologia e Parasitologia, Instituto de Ciências Biomédicas, Universidade Federal de Uberlândia, Av. Pará 1720, 38400-902 Uberlândia, MG, Brasil **Laboratório de Imunologia, Departamento de Análises Clínicas, Toxológicas e Bromatológicas, Faculdade de Ciências Farmacêuticas de Ribeirão Preto, Ribeirão Preto, SP, Brasil
\end{abstract}

The present study was conducted to detected IgG antibodies using Strongyloides venezuelensis alkaline extract for the diagnosis of human strongyloidiasis by the enzyme-linked immunosorbent assay (ELISA). Sera from 90 subjects were analyzed (30 with strongyloidiasis, 30 with other parasites and 30 healthy individuals). Results were expressed in antibody titers, which were considered as positive when titer was $\geq 80$. Sensibility and specificity of the assay were 100\% and 96.7\%, respectively. It can be concluded that the heterologous alkaline extract could be employed in ELISA as a diagnostic aid in human strongyloidiasis, due to its advantages as easiness of obtaining, practicability in preparing, and high indexes of sensitivity and specificity.

Key words: Strongyloides venezuelensis - strongyloidiasis - diagnosis - enzyme-linked immunosorbent assay

Strongyloides stercoralis infects 30 million people in 70 countries. Infection usually results in asymptomatic chronic disease of the gut, which can remain undetected for decades (Siddiqui \& Berk 2001). Due to the fluctuations on the larvae shedding in subjects infected with $S$. stercoralis, the parasitological methods have shown low sensitivity, being necessary repeated stool exams (Dreyer et al. 1996, Uparanukraw et al. 1999). Complementary tests for the diagnosis and the monitoring of the immune response in this parasitosis have been developed. However, the major limitation for the standardization of immunological methods is the difficulty in obtaining large amount of $S$. stercoralis larvae (Sato et al. 1995, Costa-Cruz et al. 1997).

The aim of this study was to diagnose human strongyloidiasis by enzyme-linked immunosorbent assay (ELISA) using alkaline extract of $S$. venezuelensis filariform larvae. The study received approval from the Ethical Committee of the Federal University of Uberlândia.

Strain of $S$. venezuelensis was isolated from feces of the wild rodent Nectomys squamips in August 1988 and maintained by experimental infection in Rattus

Financial support: Capes and Fapesp

${ }^{+}$Corresponding author. Fax: +55-34-3218.2333. E-mail: costacruz@ufu.br

Received 8 March 2003

Accepted 1 July 2003
norvergicus-Wistar. Infective larvae of $S$. venezuelensis were obtained from the feces of rats experimentally infected and cultured in mineral charcoal for two days at room temperature. Larvae were recovered by the Rugai et al. (1954) method and washed five times in 0.01 M phosphatebuffered saline (PBS) pH 7.2 containing $400 \mathrm{IU} / \mathrm{ml}$ of benzyl penicilin and $2 \mathrm{mg} / \mathrm{ml}$ of streptomycin sulfate and then stored at $-70^{\circ} \mathrm{C}$ in $\mathrm{PBS}$ until the antigen preparation. Alkaline extract of 100,000 larvae of $S$. venezuelensis was prepared by adding $1 \mathrm{ml}$ of $0.15 \mathrm{M} \mathrm{NaOH}$ (Merck, Germany) during $6 \mathrm{~h}$ under slow agitation at $4^{\circ} \mathrm{C}$. Subsequently, 0.5 $\mathrm{ml}$ of $0.3 \mathrm{M} \mathrm{HCl}$ (Merck) was added until reaching the $\mathrm{pH}$ 7.0 , and this preparation was centrifuged at $10,000 \mathrm{~g}$ for 30 min at $4^{\circ} \mathrm{C}$. Protein determination of the supernatant was $240 \mu \mathrm{g} / \mathrm{ml}$ as detected by the Lowry et al. (1951) method.

ELISA was carried out using polystyrene microplates (Difco, São Paulo, Brazil) and the reagents were assayed in $50 \mu \mathrm{l} /$ well. The plates were coated with alkaline extract at $10 \mu \mathrm{g} / \mathrm{ml}$ in $0.06 \mathrm{M}$ carbonate-bicarbonate buffer, $\mathrm{pH} 9.6$ and incubated overnight at $4^{\circ} \mathrm{C}$. The plates were washed three times for 5 min with PBS containing $0.05 \%$ Tween 20 (PBS-T) and incubated with the serum samples, including positive and negative control sera, diluted at 1:80 in PBS$\mathrm{T}$ for $45 \mathrm{~min}$ at $37^{\circ} \mathrm{C}$. After new washing as previously described, the conjugate rabbit anti-human IgG (Fc chain specific) labeled with peroxidase (Sigma, US) diluted at $1: 2,000$ in PBS-T was added and incubated for $45 \mathrm{~min}$ at $37^{\circ} \mathrm{C}$. After washing, the enzymatic substrate consisting of $\mathrm{H}_{2} \mathrm{O}_{2}$ (Merck) plus o-phenylenediamine (OPD) diluted in $0.1 \mathrm{M}$ citrate- $\mathrm{Na}_{2} \mathrm{HPO}_{4}$ buffer $\mathrm{pH} 5.5$ was added. The reaction was stopped after $15 \mathrm{~min}$ with $20 \mu \mathrm{l} /$ well of $1 \mathrm{M}$ $\mathrm{H}_{2} \mathrm{SO}_{4}$ and the absorbance values were determined in an 
ELISA reader (Metrolab, Argentina) at $490 \mathrm{~nm}$. The cut off was set using the mean absorbance values obtained from 5 non-reactive sera plus two standard deviations, considering titers $\geq 80$ as criteria of positivity.

To evaluate sensitivity and specificity of the assay using this extract, 90 serum samples from subjects living in Uberlândia, state of Minas Gerais, Brazil, were studied. This region is considered as hyperendemic area of strongyloidiasis with $13 \%$ of positivity rate in children of the urban area, as reported by Machado and Costa-Cruz (1998). Out of 90 sera, 60 samples were from subjects with positive fecal exams by the Ritchie (1948) method performed at the Clinics Hospital of the Federal University of Uberlândia, Brazil. From these, 30 were from subjects shedding only $S$. stercoralis larvae in the feces and 30 were from patients with other parasites: hookworm (5 cases), Enterobius vermicularis (5 cases), Hymenolepis nana (5 cases), Trichuris trichiura (5 cases), Ascaris lumbricoides (5 cases) and Giardia lamblia (5 cases). The 30 remaining samples were from healthy students of the biomedical area of the same University, who had three negative fecal samples by the Baermann (1917) and Hoffman et al. (1934) parasitological methods, and with no previous history of strongyloidiasis, serving as control group.

Figure gives absorbance values obtained by ELISA using $S$. venezuelensis alkaline extract. Sensitivity and specificity of ELISA were $100 \%$ and $96.7 \%$, respectively. The cut-off value was 0.371 for sera initially diluted at $1: 80$. When considering a gray zone ranging $-10 \%$ to $+10 \%$ of cut-off value, values between 0.334 and 0.408 were obtained. Thus, five sera $(16.7 \%)$ of the $S$. stercoralis positive group, no serum sample $(0 \%)$ of the group with other parasites, and only one $(3.3 \%)$ of the negative control group were found in this range. These results still shown high sensitivity and specificity values, such as $83.3 \%$ and $93.4 \%$, respectively. The distribution of the specific IgG titers by ELISA is demonstrated in Table. Antibody titers in sera from patients with strongyloidiasis ranged from 80 to 2560 .

Once the patients shedding larvae in the feces were considered as gold standard, the detection of circulating IgG antibodies should be expected in all of them. The sensitivity $(100 \%)$ of this assay for the detection of specific IgG was identical to that found by Conway et al. (1993) when using saline extract of $S$. stercoralis in a sampling of 40 patients, and higher than those reported by Neva et al. (1981) and Gam et al. (1987) that used saline extract of

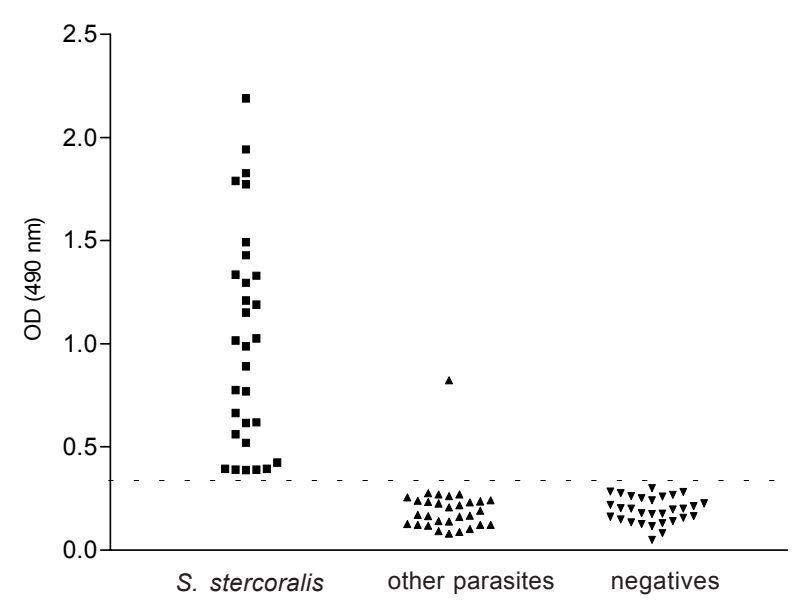

Results of serum samples (diluted 1:80) from 30 patients with Strongyloides stercoralis, 30 with other parasites and 30 negatives obtained by enzyme-linked immunosorbent assay (ELISA) using Strongyloides venezuelensis alkaline extract. OD: optical density; ---- cut-off value.

S. stercoralis or S. ratti. Using the gray zone criteria, our results were similar to the findings of the two last authors and were going to be more realistic interpreted. Specificity above $90 \%$ was demonstrated by Genta (1988) and Lindo et al. (1994) that assayed homologous saline extracts as antigen. A single serum was reactive to other parasites (hookworm) with titer of 160 . We are more than $2,500 \mathrm{~km}$ far from the endemic area for filariasis in our country (located in the northeastern region) and the conclusions about specificity should be restricted to non-endemic areas to filariasis.

The results showed that the alkaline extract of $S$. venezuelensis filariform larvae could be used as heterologous antigen for the diagnosis of human strongyloidiasis. The advantages include the easiness of maintaining and obtaining S. venezuelensis in laboratory as alternative source of antigen, easy preparation and yield of large antigen amounts without requiring sophisticated equipments and expensive reagents, and relatively short time in preparing the alkaline extract. The preparation of alkaline extract of $S$. venezuelensis filariform larvae obtained from experimental infected rats yields a large amount that makes available its utilization in large scale testing. In addition, there is

TABLE

Distribution of the titers from IgG anti-Strongyloides stercoralis detected by enzyme-linked immunosorbent assay (ELISA) using $S$. venezuelensis alkaline extract in 30 sera of $S$. stercoralis positivy subjects and 60 controls

\begin{tabular}{|c|c|c|c|c|c|c|c|c|c|c|}
\hline \multirow[b]{2}{*}{ Sera } & \multicolumn{8}{|c|}{ Alkaline extract antigen titers of IgG } & \multicolumn{2}{|c|}{ Total positive } \\
\hline & $\mathrm{Nr}$ & $<80$ & 80 & 160 & 320 & 640 & 1280 & 2560 & $\mathrm{Nr}$ & $\%$ \\
\hline$+/$ S. stercoralis & 30 & 0 & 5 & 8 & 7 & 8 & 1 & 1 & 30 & 100 \\
\hline +/Other parasites & 30 & 29 & & 1 & & & & & 1 & 3.3 \\
\hline Negatives & 30 & 30 & & & & & & & 0 & 0 \\
\hline
\end{tabular}

+ : positive by parasitological methods; Nr: numbers of individuals 
the elimination of the risk of infection during the handling of the parasite by the technicians. It can be concluded that ELISA using S. venezuelensis alkaline extract showed high sensitivity and specificity for the detection of specific serum IgG, and could be employed as a diagnostic aid in human strongyloidiasis.

\section{REFERENCES}

Baermann G 1917. Eine Einfache Methode Zur Auffindung von Ankylostomum (Nematoden) Larven in Erdproben. Mededeel mit. h. Geneesk, Lab Weltevreden Feestbundel, Batavia, p. 41-47.

Conway DJ, Atkins NS, Lillywhite JE, Bailey JW, Robinson RD, Lindo JF, Bundy DAP, Bianco AE 1993. Immunodiagnosis of Strongyloides stercoralis infection: a method for increasing the specificity of the indirect ELISA. Trans $R$ Soc Trop Med Hyg 87: 173 - 176.

Costa-Cruz JM, Bullamah CB, Gonçalves-Pires MRF, Campos DMB, Vieira MA 1997. Cryo-microtome sections of coproculture larvae of Strongyloides stercoralis and Strongyloides ratti as antigen sources for the immunodiagnosis of human strongyloidiasis. Rev Inst Med Trop São Paulo 39: 313-317.

Dreyer G, Fernandes-Silva E, Alves S, Rocha A, Albuquerque R, Addiss D 1996. Patterns of detection of Strongyloides stercoralis in stool specimens: implications for diagnosis and clinical trials. J Clin Microbiol 34: 2569-2571.

Gam AA, Neva FA, Krotoski WA 1987. Comparative sensitivity and specificity of ELISA and IHA for serodiagnosis of strongyloidiasis with larval antigens. Am J Trop Med Hyg 37: 157-161.

Genta RM 1988. Preditive value of an enzyme-linked immunosorbent assay (ELISA) for the serodiagnosis of strongyloidiasis. Am J Clin Pathol 89: 391-394.

Hoffmann WA, Pons JA, Janer JL 1934. The sedimentation concentration method in schistosomiasis mansoni. Puerto Rico J Public Health Trop Med 9: 283-291.

Lindo JF, Conway DJ, Atkins NS, Bianco AE, Robinson RD, Bundy DAP 1994. Prospective evaluation of enzyme-linked immunosorbent assay and immunoblot methods for the diagnosis of endemic Strongyloides stercoralis infection. Am J Trop Med Hyg 51: 175-179.

Lowry OH, Rosebrough NJ, Farr AL, Randall RJ 1951. Protein measurement with the folin phenol reagent. $J$ Biol Chem 193: 265-275.

Machado ER, Costa-Cruz JM 1998. Strongyloides stercoralis and other enteroparasites in children at Uberlândia city, state of Minas Gerais, Brazil. Mem Inst Oswaldo Cruz 93: 161-164.

Neva FA, Gam AA, Burke J 1981. Comparison of larval antigens in an enzyme-linked immunosorbent assay for strongyloidiasis in humans. J Infect Dis 144: 427-432.

Ritchie LS 1948. An ether sedimentation technique for routine stoll examination. Bul N S Army Med Dep 8: 326-334.

Rugai E, Mattos T, Brisola AP 1954. Nova técnica para isolar larvas de nematóides das fezes: modificações do método de Baermann. Rev Inst Adolfo Lutz 14: 5-8.

Sato Y, Kobayashi J, Shiroma Y 1995. Serodiagnosis of strongyloidiasis. The application and significance. Rev Inst Med Trop São Paulo 37: 35-41.

Siddiqui AA, Berk SL 2001. Diagnosis of Strongyloides stercoralis infection. Clin Infect Dis 33: 1040-1047.

Uparanukraw P, Phongsri S, Morakote N 1999. Fluctuations of larval excretion in Strongyloides stercoralis infection. Am J Trop Med Hyg 60: 967-973. 